\title{
Overview and Imaging of Orbital Tumors
}

\author{
Zeynel A. Karcioglu
}

\section{Incidence of Orbital Tumors}

\section{Primary Tumors of Orbit}

Although the incidence of different orbital tumors varies considerably among large series, it is plausible to group the orbital space-occupying lesions as $60 \%$ benign and $40 \%$ malignant pathologies in adults.

The frequency of malignancy is about $20 \%$ among young patients within the age range of 1-18 years. The incidence of malignant tumors upsurges with aging chiefly because of the higher prevalence of lymphomas and metastatic tumors [1-9].

Another approach to classification is to divide the orbital tumors as cystic or partially cystic, versus solid lesions; in adults this ratio is about $30 \%$ and $70 \%$ respectively. The percentage of cystic lesions is higher in younger age groups primarily because of the common occurrence of dermoid and other congenital hamartomas (vascular and others) and rarely as a result of cystic degeneration within some solid tumors such as meningioma and schwannoma in children [10-11].

The most common diagnoses in all age groups are vascular hamartomatous lesions [infantile hemangioma, cavernous malformations, and

\footnotetext{
Z. A. Karcioglu $(\bowtie)$

Department of Ophthalmology,

University of Virginia, Charlottesville, VA, USA

e-mail: zak8g@virginia.edu
}

venolymphatic malformations] representing approximately $15-20 \%$ of all orbital masses. Lymphoproliferative lesions and lacrimal fossa masses represent between $10 \%$ and $15 \%$, while non-specific orbital inflammatory lesions, optic nerve tumors [glioma and meningioma], and secondary masses from regional tumors all represent between $5 \%$ and $10 \%$. Metastatic tumors from a systemic primary disease may represent approximately $5 \%$ of orbital disease. Mesenchymal lesions such as schwannoma, rhabdomyosarcoma, osteogenic tumors, etc. are encountered much less frequently, usually below 2-3\% in large series.

The most frequently encountered primary orbital tumors in adults are lymphoproliferative lesions and cavernous malformations. In children, the most common orbital tumors tend to be cystic and benign including dermoid cysts and vascular lesions [infantile hemangioma, venolymphatic malformations]. Less common malignancies include rhabdomyosarcoma, histiocytic tumors, Burkitt's lymphoma, neuroblastoma, Ewing sarcoma, Wilms tumor, and leukemia [12-13].

\section{Metastatic Tumors of Orbit}

The prevalence of metastatic neoplasms to orbit has increased in recent decades, due to increased numbers of cancer patients in general, viral epidemics, higher levels of UV and chemical exposures. Further, improved treatments have 
led to an upsurge in the median survival of these patients, which may increase the risk of developing metastatic lesions throughout the body, including the orbit. An improved level of awareness for orbital metastases has increased detection of these lesions across all disciplines of medicine.

Recent cumulative data indicates that the most commonly affected regions of the orbit with metastatic tumors are lateral (40\%), superior (30\%), medial (20\%), and inferior (10\%) quadrants [14]. Another report claims that the anterior orbit, adjacent to lymphatic rich conjunctiva and eyelids, is most commonly involved with metastatic tumors [15].

Some malignancies show distinct tissue selectivity in metastatic disease, for instance, prostate cancer tends toward bone, breast to orbital fat, and carcinoid tumor to muscle. These tendencies can aid in diagnostic planning.

In about $25 \%$ of the cases, there may be no history of systemic cancer at the time of orbital tumor presentation. Similar to primary tumors of the orbit, most common presenting signs and symptoms include rapidly developing proptosis and associated eyelid and conjunctiva anomalies, pain, diplopia, and rarely isolated optic neuropathy and enophthalmos. Because of the rapid growth of the malignant neoplasm, the motility disturbance may be out of proportion to the degree of proptosis. Enophthalmos is rare and typically seen in sclerotic carcinomas or after radiation therapy of a preceding orbital mass. Isolated metastases to the eyelid and periocular skin and eyelids are rare [16-17].

Most commonly encountered secondary and metastatic tumors in adult orbit are squamous cell carcinoma (SCC) of paranasal sinuses, meningiomas from CNS and breast, lung and prostate cancers respectively [14].

\section{General Considerations in Orbital Tumor Patient}

During the patient assessment process, it is vital to establish a good rapport with the patient and the family, which will fortify their trust with the surgeon. It is further critical that the patient's problem be discussed in detail at every step of management as cancer is usually a serious issue with high morbidity and mortality. If possible, the images of MRI or CT revealing a spaceoccupying mass in the orbit should be shared with the patient and the family; the obvious difference between the tumor containing orbit and the normal one is usually very informative and convincing for the patient. Furthermore, the reasons for surgery, the expected benefits, and especially potential complications should be discussed in an open manner. If the case is inoperable, alternative management plans should be debated. It is most important that the patient and the family, not the surgeon, decide whether to proceed with surgery. It should be carefully explained that the orbital problem may be part of a systemic disease and that better understanding of the orbital pathology may eventually help to arrive at an effective systemic treatment.

\section{Clinical Evaluation of Orbital Tumor Patient}

The evaluation of the orbit begins with a thorough history and physical examination. Detailed systemic and ocular inquiries offer many useful clues. The family history should specify any cancer, craniofacial abnormalities, and other systemic familial diseases such as neurofibromatosis. A history of previous hospitalizations, head and neck injuries, and surgeries should be investigated. A list of the patient's medications and allergies should be obtained and a tendency toward bleeding should specifically be elicited. Anticoagulants and chemicals which may affect bleeding should be noted and appropriately addressed by cessation at an appropriate interval prior to surgery or managed in conjunction with an internist/hematologist.

Special emphasis on the duration and speed of progression of the symptoms should be heard in the patient's own words. Symptoms such as displacement of the eye(s), pain, tenderness, diplopia, pulsation, change in the degree of proptosis with position or Valsalva maneuver, and disturbance of visual acuity and/or visual fields are typically elicited [18-19]. 
A complete ophthalmic examination including assessment of visual acuity, visual field, extraocular motility, anterior and posterior segments, sensory capacity and cranial is essential. Periorbital/ orbital changes such as proptosis, abnormal eyelid configuration, skin lesions, edema, chemosis, and the appearance of conjunctival vessels should be carefully evaluated and photographs should be obtained if possible. Apposition and motility abnormalities of the eyelids and the status of lacrimal drainage system (LDS) are additional key points to be checked during the examination.
Diminished or changing visual acuity, color vision, abnormal visual fields, and pupillary abnormalities are important to note. Motility dysfunction and diplopia should be carefully assessed and quantified if possible by Hess screen and/or alternating prism cover test throughout the course of illness. Intraocular pressure should be elevated. Slit lamp examination can discern chemosis, congested tortuous vessels. Dilated indirect ophthalmoscopy may reveal optic disc edema or pallor, retinal detachment, choroidal folds, scleral indentation, vascular engorgement or shunt vessels [19-21].
Fig. 10.1 Checking the position of the globes with Hertel's exophthalmometer $(\mathbf{a}, \mathbf{b})$; "Worm's eye view" examination of proptosis of the left eye secondary to a large space occupying lesion in the orbit; (c) Axial CT image showing left eye proptosis (d)
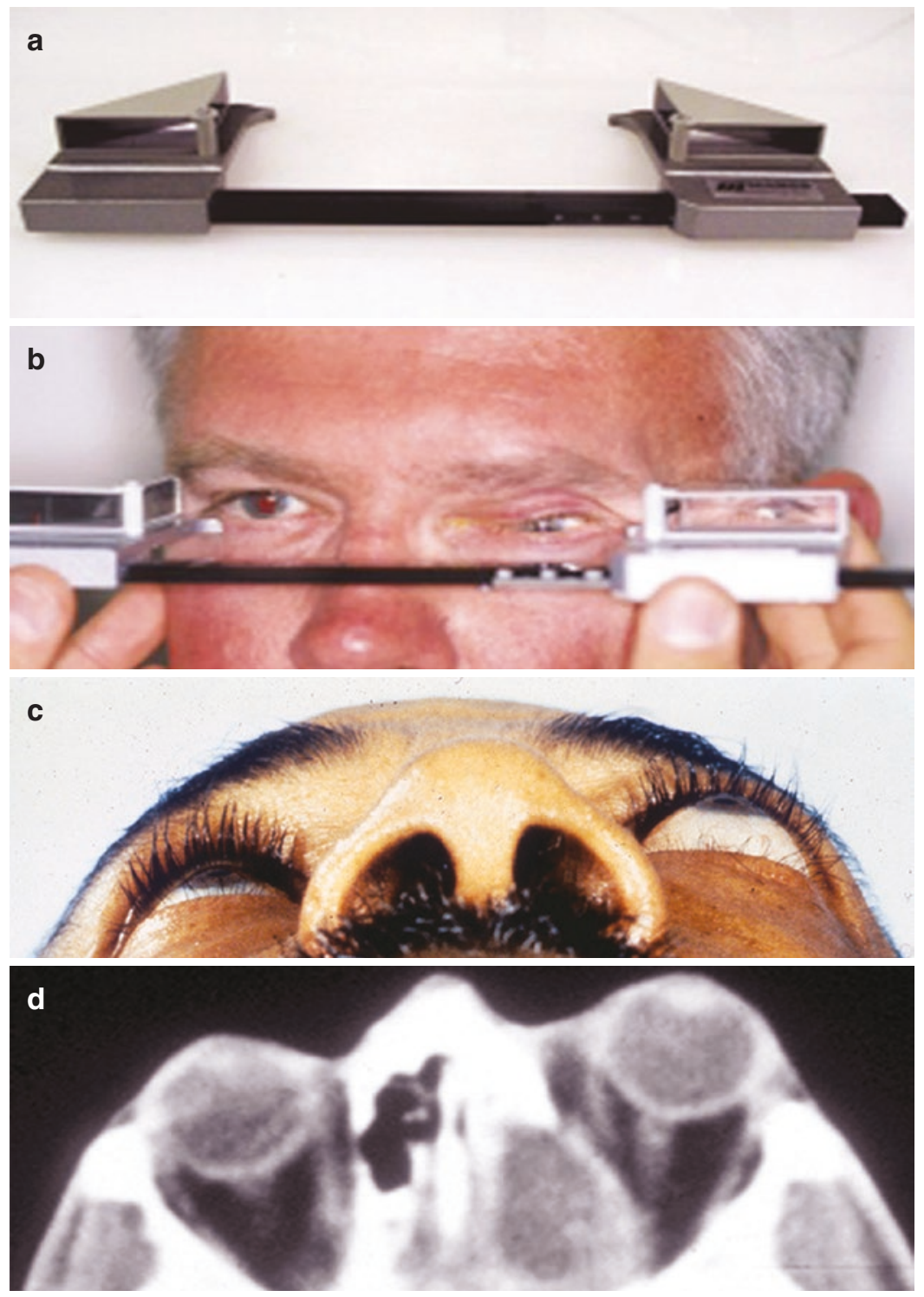
Bilateral or unilateral displacement of the eye (proptosis) is an important clinical manifestation of orbital space-occupying lesions. In addition to axial proptosis, one should note the displacement of the eye in planes other than the antero-posterior direction, vertical and lateral globe dystopia should be documented. The degree of displacement, compared to the fellow eye is generally quantified in millimeters with exophthalmometry (typically with Hertel Exophthalmometer) (Fig. 10.1). If an exophthalmometer is not available, the relative protrusion can be observed by simply standing behind a seated patient and gazing downward from the forehead to assess the displacement of one globe compared to the other. Alternatively, this can be noted by having the patient elevate the head and looking from below the nose or "worm'seye" view. The displacement (proptosis) of the eye is estimated based on the distance (in millimeters) in an anterior-posterior plane between the anterior surface of the cornea and the anterior margin malar eminence. This distance normally varies from 16.5 to $21.5 \mathrm{~mm}$ in Caucasian men and $15.5-20 \mathrm{~mm}$ in Caucasian women. In African American adults, the measurements are increased by approximately $2 \mathrm{~mm}$ in both sexes (Fig. 10.2) [22-24].

External examination for orbital pathology must include the changes of the eyelids, conjunctiva, and periorbital skin and the underlying soft tis-
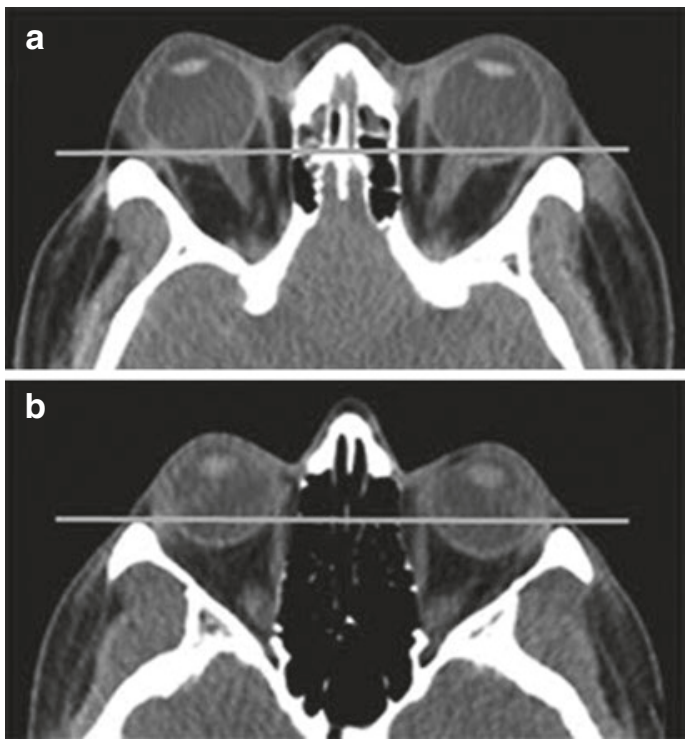

Fig. 10.2 (a, b) Normal anatomy of orbits in white and black women in CT. (From Karcioglu [8], with permission) sues. Regional lymph nodes should be examined. Edema, discoloration, and tenderness of these tissues may provide information regarding the orbital process. Edema of the eyelids without erythema or other inflammatory signs may be associated with vascular and neurogenic tumors, presumably secondary to long-standing venous stasis. Edema with inflammatory signs such as hyperemia and/ or tenderness is commonly associated with thyroid eye disease (particularly if in association with eyelid retraction) and orbital inflammatory syndromes (infectious and non-infectious, specific and nonspecific). Ecchymosis should not be confused with hyperemia (Fig. 10.3). The former is often seen in metastatic neuroblastoma but may also be encountered with amyloidosis, plasmacytoma, and leukemic infiltrates. A typical feature of ecchymosis, secondary to neuroblastoma, is its changing appearance from day to day [25].

Xanthelasmas on the periorbital skin should also be noted, since they may be a part of orbital xanthogranuloma or systemic disease (Fig. 10.4) [26-27].

Lesions palpable in the anterior orbit can be evaluated for mobility and the solid versus cystic

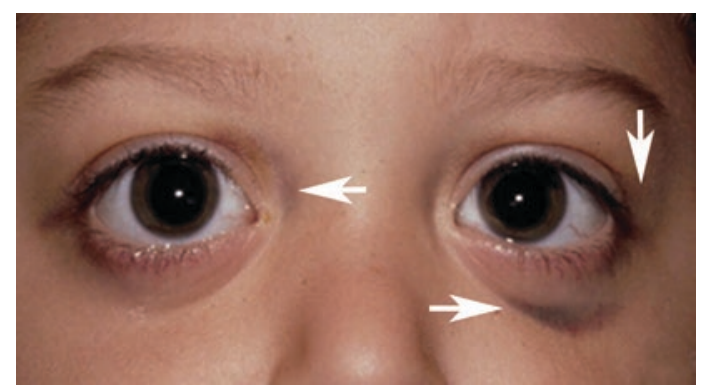

Fig. 10.3 Bilateral ecchymosis in a patient with metastatic neuroblastoma. (From Karcioglu [8], with permission)

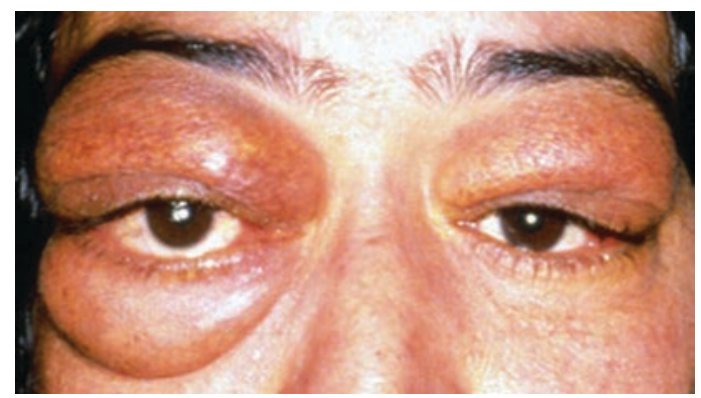

Fig. 10.4 Bilateral upper lid xanthelasmas in the patient. (From Karcioglu [8], with permission) 

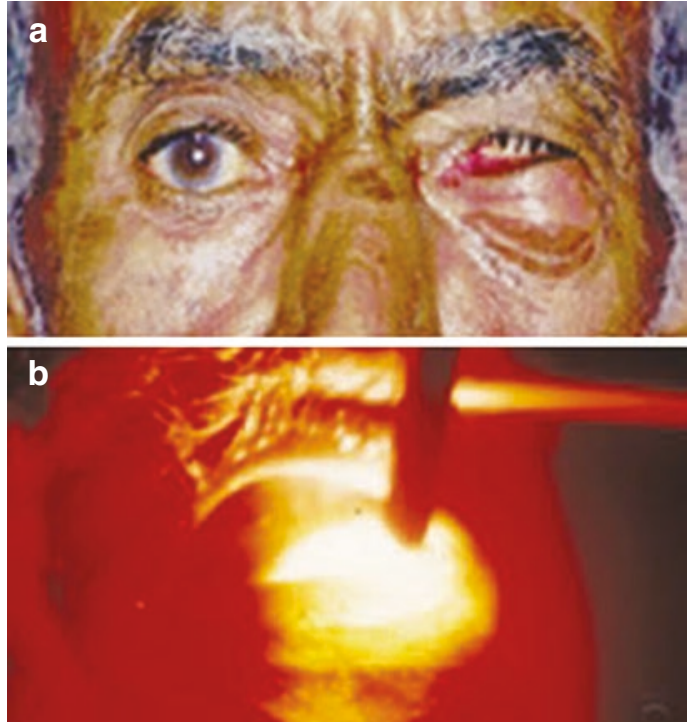

Fig. 10.5 (a, b) Transillumination of cystic basal cell carcinoma in inferior orbit displacing the globe superiorly. (From Karcioglu [8], with permission)

nature of the mass and its relationship to orbital bones and to other underlying tissues. Some anterior cystic masses can be transilluminated over the skin (Fig. 10.5).

Retropulsion is the degree of posterior freedom of movement of the globe which can be tested by the examiner's hand, pushing over patient's closed lids without creating too much discomfort. Tactile examination is also helpful to reveal pulsations of the globe secondary to arteriovenous communications and occasionally crepitations in an emphysematous orbit. Auscultation of the orbit may rarely detect a bruit, secondary to A-V malformations or carotid-cavernous fistula but it is of vital importance to recognize this sign clinically. Attention should also be paid to regional lymph nodes for enlargement and tenderness. Certain types of clinical laboratory tests may also be helpful throughout the diagnosis and management of the tumor patient (Table 10.1).

\section{Imaging in Orbital Tumor Patient}

Whereas many pathologic processes intrinsic to the globe may be easily evaluated under direct visualization, radiological imaging is of greater value in the evaluation of orbital and intracranial processes. In current practice, imaging including CT and MRI is the gold standard for diagnosis
Table 10.1 Laboratory tests for orbital tumor patient

Tests to screen for cancer or precancerous conditions

Tumor marker tests measure the presence, levels, or activity of specific proteins or genes in tissue and blood that may be signs of cancer

Tests for cancer gene mutations

For example, searching for BRCA1 and BRCA2 mutations that play a role in the development of breast, ovarian, and other cancers

Tests to screen for immune status of the patient

Tests for antibody deficiency: $\mathrm{IgG}$, IgA and IgM levels in blood

Tests for evaluation of cellular (T-cell) immunity

Tests for evaluation of neutrophil function

Tests for evaluation of complement: hemolytic complement assay or $\mathrm{CH} 50$

Tests to determine HIV/AIDS, HPV, EB and other virus positivity when indicated

Pre-operative and post-operative tests to assure a safe surgical course

Complete blood count (CBC) and clotting studies including prothrombin time (PT), activated partial thromboplastin time (aPTT), and thrombin time (TT), to assess blood clotting function of the patient

Tests to diagnose cancer at the time of biopsy

Frozen-section, histopathology,

immunohistochemistry, Immunophenotyping

Flow-cytometry, DNA sequencing and antibody/gene microarray, PCR, quantitative PCR

Tests to make a management plan

Confirmation of tumor type and staging for chemo and radiation treatments

Tests to determine the dissemination of cancer; sentinel node biopsy; LP cytology; BM biopsy

Tumor marker tests to measure the presence, levels, or activity of specific proteins or genes in tissue and blood that may indicate the presence of cancer. A tumor that shows greater than normal level of a certain tumor marker may respond to treatment with a drug targeting that specific marker

Tests to monitor the patient during treatment and look for adverse effects of the treatment

Urinalysis; CBC; blood chemistry; tests detect metabolites, electrolytes, fats, and proteins, and enzymes including blood urea nitrogen (BUN) and creatinine and many others

Tests to determine whether the tumor is responding to treatment and tests to monitor recurrence

Clinical Laboratory tests can be useful for orbital tumor patient for numerous purposes. Although many of these tests are only available in major medical and research centers, the spectrum of laboratory capabilities is important to appreciate

and management [28-31] (Tables 10.2, 10.3, $10.4,10.5,10.6$ and 10.7).

$\mathrm{CT}$ and MRI, independently or together, provide a wealth of information on orbital lesions. Each has 
Table 10.2 Imaging protocols for CT and MRI

Routine imaging protocol for orbit and brain CT

The standard orbital CT protocol calls for the acquisition of $0.625 \mathrm{~mm}$ axial source images which are then reconstructed as overlapping $1.25 \mathrm{~mm}$ slices and also converted into soft tissue and bone algorithms. Additionally, overlapping $1.5 \mathrm{~mm}$ sagittal and coronal reformatted images are routinely generated

Routine imaging protocol for orbit and brain MRI

Generally speaking, T1-weighted images provide the best overall anatomic detail. Several tissues demonstrate high T1 signal: fat, subacute blood, and often melanin. Tissues with high fluid content (such as edema) demonstrate high T2 intensity. Fat-suppressed sequences are typically performed in the orbit to allow for differentiation of hyperintense structures from the underlying normal fat, for instance, in contrast-enhanced sequences. Diffusion weighted images (DWI) and the apparent diffusion coefficient (ADC) help to evaluate ischemic tissues and cellular tumors like lymphomas, which can be bright on DWI and dark on ADC. Today MRI is most commonly performed with $1.5 \mathrm{~T}$ units using either head or surface coils

$M R A$ and $M R V$

Magnetic resonance angiography and venography may be added to conventional MRI protocols when differential diagnosis includes cavernous carotid fistula, arterial dissection, vascular malformations or other vascular anomalies

Data from ICRP statement on tissue reactions. International Committee on Radiological Protection [33]; Belden and

Zinreich [34]; Sepahdari et al. [35] and Lee et al. [36]

Table 10.3 Advantages and disadvantages of CT and MRI

\begin{tabular}{l|l|l}
\hline & Advantages & Disadvantages \\
\hline \multirow{2}{*}{$C T$} & Low cost & Ionizing radiation \\
\cline { 2 - 3 } & Availability and fast scanning time & Contrast reaction \\
\cline { 2 - 3 } & Good detail of bone anatomy & Beam-hardening and other artifacts \\
\hline \multirow{2}{*}{ SRI } & Superior detail of anatomy & $\begin{array}{l}\text { Incompatible with a number of metallic implantable } \\
\text { medical devices and foreign bodies }\end{array}$ \\
\cline { 2 - 3 } & No ionizing radiation & Motion and other artifacts \\
\cline { 2 - 3 } & & High cost, longer scanning times \\
\hline
\end{tabular}

Table 10.4 MRI features of well-delineated orbital lesions (appearance and signal with respect to vitreous)

\begin{tabular}{|c|c|c|c|c|c|}
\hline & Orbital lesions & $\begin{array}{l}\text { T1-weighted } \\
\text { image }\end{array}$ & $\begin{array}{l}\text { T2-weighted } \\
\text { image }\end{array}$ & $\begin{array}{l}\text { Enhancement with } \\
\text { Gd-DTPA }^{\text {a }}\end{array}$ & Comments \\
\hline \multirow[t]{2}{*}{1} & \multirow{2}{*}{$\begin{array}{l}\text { Lymphoproliferative } \\
\text { disorders }\end{array}$} & Homogenous & Homogenous & \multirow[t]{2}{*}{ Homogenous } & \multirow{2}{*}{$\begin{array}{l}\text { Oval, lobulated, } \\
\text { molding to other } \\
\text { structures }\end{array}$} \\
\hline & & $\begin{array}{l}\text { Iso-/ } \\
\text { hyperintense }\end{array}$ & $\begin{array}{l}\text { Iso-/ } \\
\text { hypointense }\end{array}$ & & \\
\hline \multirow[t]{2}{*}{2} & \multirow[t]{2}{*}{ Cavernous malformation } & Homogenous & Homogenous & $\begin{array}{l}\text { Heterogenous } \\
\text { early, } \\
\text { homogenous late }\end{array}$ & \multirow[t]{2}{*}{$\begin{array}{l}\text { Well delineated round } \\
\text { frequently intraconal }\end{array}$} \\
\hline & & $\begin{array}{l}\text { Iso-/ } \\
\text { hyperintense }\end{array}$ & $\begin{array}{l}\text { Iso-/ } \\
\text { hyperintense }\end{array}$ & ++++ & \\
\hline \multirow[t]{2}{*}{3} & \multirow[t]{2}{*}{ Orbital metastasis } & $\begin{array}{l}\text { Homo-/ } \\
\text { heterogenous }\end{array}$ & $\begin{array}{l}\text { Homo-/ } \\
\text { heterogenous }\end{array}$ & $\begin{array}{l}\text { Homogenous/ } \\
\text { rarely cystic }\end{array}$ & \multirow{2}{*}{$\begin{array}{l}\text { May be associated with } \\
\text { sinus, lymphatic or } \\
\text { intracranial lesions }\end{array}$} \\
\hline & & $\begin{array}{l}\text { Iso-/ } \\
\text { hyperintense }\end{array}$ & $\begin{array}{l}\text { Iso-/ } \\
\text { hyperintense }\end{array}$ & $+/++$ & \\
\hline \multirow[t]{2}{*}{4} & \multirow{2}{*}{$\begin{array}{l}\text { Peripheral nerve tumors } \\
\text { (schwannoma, } \\
\text { neurofibroma) }\end{array}$} & Heterogenous & Heterogenous & $\begin{array}{l}\text { Heterogenous (in } \\
\text { malignant change) }\end{array}$ & \multirow[t]{2}{*}{$\begin{array}{l}\text { Central enhancement, } \\
\text { focal cystic change }\end{array}$} \\
\hline & & $\begin{array}{l}\text { Hypo/ } \\
\text { isointense }\end{array}$ & $\begin{array}{l}\text { Hyperintense, } \\
\text { "target-sign" }\end{array}$ & $+/+++$ & \\
\hline \multirow[t]{2}{*}{5} & \multirow[t]{2}{*}{ Rhabdomyosarcoma } & Homogenous & Homogenous & Homogenous & \multirow{2}{*}{$\begin{array}{l}\text { About } 15 \% \text { intraconal, } \\
\text { other intra \& } \\
\text { extraconal }\end{array}$} \\
\hline & & $\begin{array}{l}\text { Hypo-/ } \\
\text { isointense }\end{array}$ & Hyperintense & ++++ & \\
\hline
\end{tabular}


Table 10.4 (continued)

\begin{tabular}{|c|c|c|c|c|c|}
\hline & Orbital lesions & $\begin{array}{l}\text { T1-weighted } \\
\text { image }\end{array}$ & $\begin{array}{l}\text { T2-weighted } \\
\text { image }\end{array}$ & $\begin{array}{l}\text { Enhancement with } \\
\text { Gd-DTPA }^{\mathrm{a}}\end{array}$ & Comments \\
\hline \multirow[t]{2}{*}{6} & \multirow{2}{*}{$\begin{array}{l}\text { Solitary fibrous tumor } \\
\text { (SFT) }\end{array}$} & Heterogenous & Heterogenous & Heterogenous & \multirow{2}{*}{$\begin{array}{l}\text { Can be dark on } \mathrm{T} 1 \text { and } \\
\mathrm{T} 2 \text { sequences }\end{array}$} \\
\hline & & $\begin{array}{l}\text { Iso-/ } \\
\text { hyperintense }\end{array}$ & $\begin{array}{l}\text { Iso-/hypo } \\
\text { intense }\end{array}$ & ++ & \\
\hline \multirow[t]{2}{*}{7} & \multirow[t]{2}{*}{$\begin{array}{l}\text { Optic nerve sheath } \\
\text { meningioma }\end{array}$} & Homogenous & Homogenous & $\begin{array}{l}\text { Homo-/ } \\
\text { heterogenous }\end{array}$ & \multirow{2}{*}{$\begin{array}{l}\text { "Tram track" } \\
\text { calcification, distension } \\
\text { posterior to globe }\end{array}$} \\
\hline & & Isointense & $\begin{array}{l}\text { Iso-/ } \\
\text { hyperintense }\end{array}$ & $\begin{array}{l}\text { ++++ with fat } \\
\text { suppression }\end{array}$ & \\
\hline
\end{tabular}

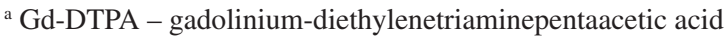

Table 10.5 MRI features of infiltrating orbital lesions (appearance and signal with respect to vitreous)

\begin{tabular}{|c|c|c|c|c|c|}
\hline & Orbital lesions & $\begin{array}{l}\text { T1-weighted } \\
\text { image }\end{array}$ & T2-weighted image & $\begin{array}{l}\text { Enhancement with } \\
\text { Gd-DTPA }^{\mathrm{a}}\end{array}$ & Comments \\
\hline \multirow[t]{2}{*}{1} & \multirow[t]{2}{*}{$\begin{array}{l}\text { Langerhans-cell and } \\
\text { non L-cell } \\
\text { Histiocytosis }\end{array}$} & $\begin{array}{l}\text { Homogenous } \\
\text { (benign or } \\
\text { malignant) }\end{array}$ & $\begin{array}{l}\text { Homogenous(benign), } \\
\text { heterogenous (malignant) }\end{array}$ & $\begin{array}{l}\text { High T2 } \\
\text { (hypercellular) }\end{array}$ & \multirow[t]{2}{*}{$\begin{array}{l}\text { Bone involvement } \\
\text { on CT }\end{array}$} \\
\hline & & $\begin{array}{l}\text { Iso-/ } \\
\text { hyperintense }\end{array}$ & & $\begin{array}{l}\text { Low T2 (less } \\
\text { cells, more } \\
\text { collagen) }\end{array}$ & \\
\hline \multirow[t]{2}{*}{2} & \multirow[t]{2}{*}{$\begin{array}{l}\text { Capillary } \\
\text { hemangioma }\end{array}$} & $\begin{array}{l}\text { Homo-/ } \\
\text { heterogenous }\end{array}$ & Homo-/heterogenous & Homogenous & \multirow{2}{*}{$\begin{array}{l}\text { Delineated } \\
\text { without capsule } \\
\text { T2 flow voids } \\
\text { occasionally }\end{array}$} \\
\hline & & $\begin{array}{l}\text { Hypo-/ } \\
\text { isointense }\end{array}$ & Iso-/hyperintense & ++++ & \\
\hline \multirow[t]{2}{*}{3} & \multirow[t]{2}{*}{ Orbital metastasis } & $\begin{array}{l}\text { Homo-/ } \\
\text { heterogenous }\end{array}$ & Homo-/heterogenous & $\begin{array}{l}\text { Homo/ } \\
\text { heterogenous }\end{array}$ & \multirow{2}{*}{$\begin{array}{l}\text { Bony infiltration } \\
\text { on CT, located } \\
\text { anywhere in orbit }\end{array}$} \\
\hline & & Hyperintense & Hypointense & $+/++++$ & \\
\hline \multirow[t]{2}{*}{4} & \multirow{2}{*}{$\begin{array}{l}\text { Orbital inflammatory } \\
\text { syndrome }\end{array}$} & Homogenous & Homogenous & \multirow{2}{*}{$\begin{array}{l}\text { Homogenous; } \\
\text { but may be } \\
\text { variable }\end{array}$} & \\
\hline & & $\begin{array}{l}\text { Iso-/ } \\
\text { hyperintense }\end{array}$ & Iso-/hypointense & & \\
\hline \multirow[t]{2}{*}{5} & \multirow[t]{2}{*}{ Neurofibromatosis } & Heterogenous & Heterogenous & Heterogenous & \multirow{2}{*}{$\begin{array}{l}\text { Can be nodular, } \\
\text { infiltrating, cystic } \\
\text { or solid }\end{array}$} \\
\hline & & $\begin{array}{l}\text { Iso-/ } \\
\text { hyperintense }\end{array}$ & Iso-/hyperintense & $+/+++$ & \\
\hline
\end{tabular}

a Gd-DTPA, gadolinium-diethylenetriaminepentaacetic acid

a role. CT has advantages in the examination of bony or other high-density lesions. Positron emission tomography (PET) CT is useful for the detection of suspicious lesions throughout the body, in the context of a potentially metastatic orbital tumor.

MRI is advantageous for delineating soft tissue processes, in that different sequences can highlight differences in cellular content of lesions and the local surrounding tissues. Special sequences such as diffusion-weighted MRI, MRI arteriography, and MRI venography can also be particularly helpful for specific suspected diagnoses. Time-resolved sequences such as TRICKS or TWIST can also be useful for vascular lesions.

Ultrasonography (US) which can be done quickly in the clinic at a low cost is uniquely suitable to reveal dynamic changes such as compressibility and internal reflectivity, as well as the cystic nature of lesions. Doppler imaging can provide information regarding vascular flow characteristics within a lesion. This modality is typically applicable primarily for anteriorly located lesions. The information US provides can also be additive to other types of imaging [32].

The most irreplaceable benefit of orbital imaging is not only to provide insight into the differential diagnosis of the tumor but also to reveal the exact localization of the pathology in the orbit. This anatomical precision allows the ophthalmologist to appropriately plan for potential surgery, whether incisional or excisional. Such improvements in preop- 
Table 10.6 MRI features of lacrimal fossa lesions (appearance and signal with respect to vitreous)

\begin{tabular}{|c|c|c|c|c|c|}
\hline & Orbital lesions & T1-weighted image & T2-weighted image & $\begin{array}{l}\text { Enhancement with } \\
\text { Gd-DTPA }^{\text {a }}\end{array}$ & Comments \\
\hline \multirow[t]{2}{*}{1} & \multirow{2}{*}{$\begin{array}{l}\text { Lympho- } \\
\text { proliferative } \\
\text { disorder }\end{array}$} & Homogenous & Homogenous & Homogenous & \multirow{2}{*}{$\begin{array}{l}\text { Diffusion-weighted } \\
\text { imaging may help to } \\
\text { detect malignancy }\end{array}$} \\
\hline & & Hyperintense & Hypointense & +++ & \\
\hline \multirow[t]{3}{*}{2} & \multirow{3}{*}{$\begin{array}{l}\text { Pleomorphic } \\
\text { adenoma (benign } \\
\text { mixed tumor) }\end{array}$} & Homogenous & Homogenous & $\begin{array}{l}\text { Homogenous } \\
\text { (small) }\end{array}$ & \multirow[t]{3}{*}{ Scalloping of orbital bone } \\
\hline & & \multirow[t]{2}{*}{ Hypo-/isointense } & \multirow[t]{2}{*}{ Iso-/hyperintense } & $\begin{array}{l}\text { Heterogenous } \\
\text { (large) }\end{array}$ & \\
\hline & & & & +++ & \\
\hline \multirow[t]{2}{*}{3} & \multirow{2}{*}{$\begin{array}{l}\text { Adenoid cystic } \\
\text { carcinoma }\end{array}$} & Heterogenous & Heterogenous & \multirow{2}{*}{$\begin{array}{l}\text { Homo-/ } \\
\text { heterogenous }\end{array}$} & Haphazard infiltration \\
\hline & & Hyperintense & Hypointense & & $\begin{array}{l}\text { Bony destruction with } \mathrm{Ca} \\
++ \text { on CT }\end{array}$ \\
\hline \multirow[t]{2}{*}{4} & \multirow[t]{2}{*}{ Dacryoadenitis } & Homogenous & Homogenous & Homogenous & \multirow[t]{2}{*}{ On CT hypo/iso to muscle } \\
\hline & & Hypo-/isointense & Iso-/hyperintense & $\begin{array}{l}\text { Variable, not very } \\
\text { helpful }\end{array}$ & \\
\hline \multirow[t]{2}{*}{5} & \multirow[t]{2}{*}{ Dacryops } & Homogenous & Homogenous & \multirow{2}{*}{$\begin{array}{l}\text { Minimal, } \\
\text { homogenous }\end{array}$} & \multirow{2}{*}{$\begin{array}{l}\text { Cyst with fluid density on } \\
\text { contrast enhanced CT }\end{array}$} \\
\hline & & Iso-/hyperintense & Hypo-/isointense & & \\
\hline
\end{tabular}

${ }^{\text {a }}$ Gd-DTPA, gadolinium-diethylenetriaminepentaacetic acid

Table 10.7 MRI features of cystic orbital lesions (appearance and signal with respect to vitreous)

\begin{tabular}{|c|c|c|c|c|c|}
\hline & Orbital lesions & T1-weighted image & T2-weighted image & $\begin{array}{l}\text { Enhancement with } \\
\text { Gd-DTPA }^{\text {a }}\end{array}$ & Comments \\
\hline \multirow[t]{2}{*}{1} & \multirow[t]{2}{*}{ Dermoid cyst } & Heterogenous & Heterogenous & Homogenous & \multirow{2}{*}{$\begin{array}{l}\text { Perilesional } \\
\text { inflammation if } \\
\text { ruptured; bone } \\
\text { remodeling on CT } \\
\text { occasionally }\end{array}$} \\
\hline & & Hypointense & Hypo-/hyperintense & +++ & \\
\hline \multirow[t]{3}{*}{2} & \multirow[t]{3}{*}{ Epithelial cyst } & Homogenous & Homogenous & $\begin{array}{l}\text { Homogenous } \\
\text { (small) }\end{array}$ & \multirow{3}{*}{$\begin{array}{l}\text { DDx choriostoma, } \\
\text { congenital cyst, } \\
\text { colobomatous cyst }\end{array}$} \\
\hline & & \multirow[t]{2}{*}{ Iso-/hyperintense } & \multirow[t]{2}{*}{ Iso-/hypointense } & $\begin{array}{l}\text { Heterogenous } \\
\text { (large) }\end{array}$ & \\
\hline & & & & +++ & \\
\hline \multirow[t]{2}{*}{3} & \multirow[t]{2}{*}{ Hydatid cyst } & Homogenous & Homogenous & \multirow{2}{*}{$\begin{array}{l}\text { Homo-/ } \\
\text { heterogenous }\end{array}$} & \multirow{2}{*}{$\begin{array}{l}\text { Multiple cysts, may be } \\
\text { calcified }\end{array}$} \\
\hline & & Isointense & Isointense & & \\
\hline \multirow[t]{2}{*}{4} & \multirow[t]{2}{*}{ Mucocele } & Homo-/heterogenous & Homo-/heterogenous & Homogenous & \multirow{2}{*}{$\begin{array}{l}\text { High protein content; } \\
\text { high signal in } \mathrm{T} 1\end{array}$} \\
\hline & & Hypo-/isointense & $\begin{array}{l}\text { Iso-/hypo-/ } \\
\text { hyperintense }\end{array}$ & $\begin{array}{l}\text { Variable, not } \\
\text { very helpful }\end{array}$ & \\
\hline \multirow[t]{2}{*}{5} & \multirow[t]{2}{*}{ Lymphangioma } & Heterogenous & Heterogenous & \multirow{2}{*}{$\begin{array}{l}\text { Minimal, } \\
\text { homogenous }\end{array}$} & \multirow{2}{*}{$\begin{array}{l}\text { Fluid-fluid level on CT } \\
\text { and MRI }\end{array}$} \\
\hline & & Iso/hyperintense & Hyperintense & & \\
\hline \multirow[t]{2}{*}{6} & \multirow{2}{*}{$\begin{array}{l}\text { Cholesterol } \\
\text { granuloma }\end{array}$} & Heterogenous & Heterogenous & Heterogenous & Fat suppression \\
\hline & & Hyperintense & Hyperintense & $\begin{array}{l}\text { Central hyper, } \\
\text { rim hypointense }\end{array}$ & Remains high signal \\
\hline
\end{tabular}

a Gd-DTPA, gadolinium-diethylenetriaminepentaacetic acid

erative data availability have led to less invasive approaches such as anterior orbitotomies through conjunctival and skin incisions, rather than wider lateral approaches where the location is less well understood preoperatively [33-36].

\section{Summary}

As in any medical diagnostic process, the data obtained in the assessment is assembled into a plan for the patient. The history will guide the examination, and the findings will in turn guide 
the selection of ancillary procedures and often imaging. Often the differential diagnosis at this point can be narrow, and reasonably so. Based on the requirements of differentiating these diagnostic possibilities and their respective treatment modalities, a management plan is selected. It is often the case in orbital disease that a tissue sample would be required, and the critical decision will be related to whether this tissue sample is obtained in fine needle aspirate, open incisional biopsy, excisional biopsy, or en bloc resection. This decision will be based on the characteristics of the lesion, the considerations for diagnosis and treatment beyond, as well as the wishes of the patient and the capabilities of the treating team.

Acknowledgments We are grateful to Dr. Daniel Rootman, Assistant Professor, Orbital and Ophthalmic Plastic Surgery, Doheny Eye Institute, University of California, Los Angeles, for his contribution as the expert reviewer for this section.

\section{References}

1. Shields JA, Shields CL, Scartozzi R. Survey of 1264 patients with orbital tumors and simulating lesions: the 2002 montgomery lecture, part 1 . Ophthalmology. 2004;111(5):997-1008.

2. Goldberg SH, Cantore WA. Tumors of the orbit. Curr Opin Ophthalmol. 1997;8(5):51-6.

3. Carroll GS, Haik BG, Fleming JC, et al. Peripheral nerve tumors of the orbit. Radiol Clin N Am. 1999;37(1):195-202.

4. Yan J, Wu Z. Cavernous hemangioma of the orbit: analysis of 214 cases. Orbit. 2004;23(1):33-40.

5. Honavar SG, Manjandavida FP. Recent advances in orbital tumors-a review of publications from 20142016. Asia-Pac J Ophthalmol. 2017;6:153-8.

6. Perry JD, Singh AD. Clinical ophthalmic oncology: orbital tumors. 2nd ed. Berlin Heidelberg: Springer; 2014.

7. Andreasen S, Esmaeli B, Holstein SL, et al. An update on tumors of the lacrimal gland. Asia Pac J Ophthalmol (Phila). 2017;6(2):159-72.

8. Karcioglu ZA. Orbital tumors: diagnosis and treatment. 2nd ed. New York: Springer; 2015.

9. Bonavolontà G, Strianese D, Grassi P, et al. An analysis of 2480 space-occupying lesions of the orbit from 1976 to 2011. Ophthal Plast Reconstr Surg. 2013;29(2):79-86.

10. Pahwa S, Sharma S, Das CJ, et al. Intraorbital cystic lesions: an imaging spectrum. Curr Probl Diagn Radiol. 2015;44(5):437-48.
11. Narayan D, Rajak S, Patel S, Selva D. Cystic change in primary pediatric optic nerve sheath meningioma. Orbit. 2016;35(4):236-8.

12. Zwaann J, Karcioglu ZA. Benign pediatric tumors. In: Karcioglu ZA, editor. Orbital tumors: diagnosis and treatment. New York: Springer; 2015. p. 337-48.

13. Karcioglu ZA, Hadjistilianou D. Malignant pediatric tumors. In: Karcioglu ZA, editor. Orbital tumors: diagnosis and treatment. New York: Springer; 2015. p. 349-60.

14. Ahmad SM, Esmaeli B. Metastatic tumors of the orbit and ocular adnexa. Curr Opin Ophthalmol. 2007;18:405-13.

15. Shields JA, Shields CL, Brotman HK, et al. Cancer metastatic to the orbit: the 2000 Robert M. Curts lecture. Ophthal Plast Reconstr Surg. 2001;17:346-54.

16. Hartstein ME, Beisman B, Kincaid MC. Cutaneous malignant melanoma metastatic to the eyelid. Ophthalmic Surg Lasers. 1998;29:993-5.

17. Zografos L, Ducrey N, Beati D, et al. Metastatic melanoma in the eye and orbit. Ophthalmology. 2003;110:2245-56.

18. Tailor TD, Gupta D, Dalley RW, et al. Orbital neoplasms in adults: clinical, radiologic, and pathologic review. Radiographics. 2013;33(6):1739-58.

19. Karcioglu ZA, Jenkins TL. Clinical evaluation of the orbit. In: Karcioglu ZA, editor. Orbital tumors: diagnosis and treatment. New York: Springer; 2015. p. 43-53.

20. Nassr MA, Morris CL, Netland PA, Karcioglu ZA. Intraocular pressure change in orbital disease. Surv Ophthalmol. 2009;54(5):519-44.

21. De La Paz MA, Boniuk M. Fundus manifestations of orbital disease and treatment of orbital disease. Surv Ophthalmol. 1995;40(1):3-21.

22. Hertel E, Simonsz HJ. A simple exophthalmometer. Strabismus. 2008;16(2):89-91.

23. Burde R, Savino P, Trobe J. Proptosis and adnexal masses. In: Clinical decisions in neuro-ophthalmology. 2nd ed. St. Louis: CV Mosby; 1992. p. 379-416.

24. Barretto RL, Mathog RH. Orbital measurement in black and white populations. Laryngoscope. 1999;109(7. Pt 1):1051-4.

25. Smith SJ, Diehl NN, Smith BD, Mohney BG. Incidence, ocular manifestations, and survival in children with neuroblastoma: a population-based study. Am J Ophthalmol. 2010;149(4):677-82; e2.

26. Vick VL, Wilson MW, Fleming JC, Haik BG. Orbital and eyelid manifestations of xanthogranulomatous diseases. Orbit. 2006;25(3):221-5.

27. Karcioglu ZA, Sharara N, Boles T, Nasr A. Orbital xanthogranuloma: clinical morphologic features in eight patients. Ophthalmic Plast Reconstr Surg. 2003;19:372-81.

28. Müller-Forell WS. Computed tomograpy. In: MüllerForell WS, editor. Imaging of orbital and visual pathway pathology. Berlin: Springer; 2010.

29. Yousem DM, Grossman RI. Orbit. In: Yousem DM, Grossman RI, editors. The requisites. Neuroradiology. Philadelphia: Mosby/Elsevier; 2010. p. 1-20, 321-355. 
30. Gandhi RA, Nair AG. Role of imaging in the management of neuro-ophthalmic disorders. Indian $\mathrm{J}$ Ophthalmol. 2011;59:111-6.

31. Fetkenhour DR, Shields CL, Chao AN, et al. Orbital cavitary rhabdomyosarcoma masquerading as lymphangioma. Arch Ophthalmol. 2001;119: 1208-10.

32. Nasr AM, Abou Chacra GI. Ultrasonography in orbital differential diagnosis. In: Karcioglu ZA, editor. Orbital tumors: diagnosis and treatment. New York: Springer; 2015. p. 69-81.
33. ICRP statement on tissue reactions. International Committee on Radiological Protection, 2011.

34. Belden CJ, Zinreich SJ. Orbital imaging techniques. Semin Ultrasound CT MR. 1997;18:413-22.

35. Sepahdari AR, Kapur R, Aakalu VK, et al. Diffusionweighted imaging of malignant ocular masses: results and directions for further study. AJNR Am J Neuroradiol. 2012;33(2):314-9.

36. Lee AG, Johnson MC, Policeni BA, Smoker WR. Imaging for neuro-ophthalmic and orbital disease-a review. Clin Exp Ophthalmol. 2009;37:30-53.

Open Access This chapter is licensed under the terms of the Creative Commons Attribution 4.0 International License (http://creativecommons.org/licenses/by/4.0/), which permits use, sharing, adaptation, distribution and reproduction in any medium or format, as long as you give appropriate credit to the original author(s) and the source, provide a link to the Creative Commons license and indicate if changes were made.

The images or other third party material in this chapter are included in the chapter's Creative Commons license, unless indicated otherwise in a credit line to the material. If material is not included in the chapter's Creative Commons license and your intended use is not permitted by statutory regulation or exceeds the permitted use, you will need to obtain permission directly from the copyright holder. 